\title{
The scandal of modern slavery in the trade of masks and gloves
}

The coronavirus pandemic has highlighted the reliance of the NHS on disposable medical instruments and protective clothing - but their trade hides a murky world of modern slavery and labour abuse, writes Jane Feinmann

\section{Jane Feinmann freelance journalist}

London, UK

The failure of the NHS to provide adequate protective equipment for its employees-including basic items such as gloves and masks-has been among the many unpleasant shocks of the covid-19 crisis for healthcare professionals. Yet there is a murkier scandal about the procurement of these everyday items that the NHS has yet to face.

"Slavery is prospering in the 21st century-with the NHS turning a blind eye. Economics is all that matters; manufacturers try to sell at maximum profit and purchasers minimise cost," said Mahmood Bhutta, consultant in ear, nose, and throat surgery at Brighton and Sussex University Hospitals NHS Trust. Bhutta founded the Medical Fair and Ethical Trade Group in 2006. He said he feels "ashamed as a doctor to be wearing gloves manufactured using human exploitation."

Labour rights violations are widespread in the manufacture of healthcare goods globally, including disposable surgical instruments in Pakistan, surgical masks in Mexico, and healthcare uniforms in India.

\section{Gloves off}

Perhaps the most prominent allegations of abuse centre around the production of medical gloves. It's a lucrative market; 300 billion gloves were used globally in 2019 (before the covid-19 pandemic) and the NHS spends $£ 80 \mathrm{~m}(€ 92 \mathrm{~m} ; \$ 100 \mathrm{~m})$ on 1.5 billion boxes of disposable gloves every year. ${ }^{1}$

The largest rubber glove manufacturing companies is Top Glove, with an annual revenue of $£ 870 \mathrm{~m}$. It is based in Malaysia and produces gloves for multiple brands supplying NHS Supply Chain, the organisation that has a $40 \%$ share of medical goods purchased by NHS hospitals and clinics.

In 2018 and 2019, the Guardian ${ }^{2}$ and The Diplomat ${ }^{3}$ published reports accusing both companies of routine abusive labour practices including forced labour, withheld wages, passport confiscation, and recruitment fee induced debt bondage (where migrants, mainly from Bangladesh and Nepal, obtain jobs in
Malaysia by paying recruitment agencies exorbitant fees using high rate loans).

"This debt creates an extreme vulnerability to exploitation and serves to bind workers and keep them at employers' mercy," said anti-trafficking lawyer Archana Kotecha, head of legal at Liberty Shared, an anti-trafficking organisation. "Local employers, global brands, and shareholders, as well as organisations such as NHS Supply Chain, have benefited from such systemic abuses for years," sociologist Johannes Breman from Amsterdam University, an expert in modern slavery, told The BMJ.

Top Glove has denied the allegations. In a statement to The $B M J$, the company said: "The concern about abusive labour practices is unfounded. Since the implementation of a zero cost recruitment policy in January 2019, the workers we hire are not in debt bondage. We adhere to international social compliance codes of conduct. We respect human rights and have zero tolerance for labour rights abuses." The statement also said that "workers have full custody of their passports." In a 2018 statement made to the Guardian and shared with The BMJ, it said there was "absolutely no forced labour" at the company. In October 2019, the US Customs and Border Protection (CBP) agency announced an unprecedented import ban on WRP Asia Pacific, another rubber glove manufacturing company based in Malaysia, because of "evidence of multiple indicators of forced labour." A spokesman for the company said that new management had taken over in January 2020 and since then had "worked tirelessly with the relevant parties to ensure strong labour standards and frameworks wherein its labour practices are compliant with relevant regulations."

\section{Child labour}

Bhutta first became aware of the prevalence of labour rights abuse in 2005 while visiting family in Sialkot, northern Pakistan. "My cousin knew that I work as a surgeon and asked if I'd be interested in seeing how surgical instruments are manufactured." 
He discovered a huge industry manufacturing two thirds of the 150 million reusable and disposable surgical instruments in the global market. During the 17th century Mughal empire, Sialkot was a centre for the production of swords.

Alongside large, relatively modern firms, labour intensive work-filing, grinding, hammering, and polishing —was subcontracted to hundreds of small family run units, frequently including child labour, commonly causing "musculoskeletal injuries that are sometimes incapacitating," where workers have no security or medical insurance and earn on average $\$ 2$ a day.

"In my mind, I had associated surgical instruments with the clean sterile environment of the operating theatre. But here they were being ground and filed by 10 year old children working full time in small open garages-as I saw with my own eyes," he said.

"The noise was deafening, the heat and dust unbearable, the risk of serious injury palpable. It was something I thought I could and should change through my role as a surgeon-I was a trainee surgeon at the time- - though I was wary of making things worse by highlighting a problem without any solutions." Within a year, Bhutta wrote an article for The $B M J^{4}$ and helped develop the Ethical Procurement for Health workbook, jointly produced by the BMA in partnership with the Ethical Trading Initiative and the Department of Health in 2011, and updated in March 2017. ${ }^{5}$ It provided a step-by-step guide to how NHS institutions "can harness their purchasing power to improve the situation for workers who make healthcare goods—and thereby improve working conditions among the worse encountered anywhere," according to a 2017 editorial he wrote in the Bulletin of the World Health Organization. ${ }^{6}$

A key response was introduction of the Labour Standards Assurance System (LSAS) in 2012 by NHS Supply Chain, designed to drive improvements through contractual obligations to actively managing labour standards for workers.

In 2015, Bhutta revisited Sialkot with a Swedish non-governmental organisation, Swedwatch, producing a BMA report which noted "some improvements among subcontractors working for recognised exporting factories" while the problem persists among other vendors. ${ }^{7}$

\section{Pandemic pressure}

Labour abuses have continued-with the response to the coronavirus pandemic now bringing about an increase in the suffering of thousands of workers. "On paper LSAS sounded good, but it was demonstrably not fit for purpose when several gloves suppliers who had adopted the system were found to be sourcing from factories where labour rights abuse was rampant," said Bhutta.

Part of the reason is that there are other priorities. "Even without the pandemic, the voice screaming 'ethical procurement' may not get heard," he said.

With the World Health Organization warning that the "chronic global shortage of personal protective gear is among the most urgent threats to virus containment efforts," reports have emerged that a temporary reduction by $50 \%$ in the production of gloves in Malaysian factories-part of the national lockdown-has been reversed. According to the Guardian and the Telegraph, factories have been operating at $100 \%$ capacity since 1 April 2020. ${ }^{89}$

Lobbying by the Malaysian Rubber Glove Manufacturers Association throughout March was supported by both the EU and the UK in communications that appeared to make no mention of forced labour concerns. In a letter dated 20 March, reported by Reuters, ${ }^{10}$ the Department of Health and Social Care urged Malaysian authorities to prioritise the production and shipment of gloves that are of "utmost criticality for fighting covid-19."

Yet at the same time, the UK government made what is probably its strongest ever statement repudiating modern slavery, ${ }^{11}$ with Prime Minister Boris Johnson promising to "take active steps to drive this increasingly pervasive evil out of our supply chains —and then peering into the shadows to satisfy ourselves that we have succeeded in doing so.”

In a further statement on 30 March 2020, an NHS Supply Chain spokesperson told The BMJ that the organisation "takes all allegations of labour abuses in its supply chain very seriously and we have a range of contractual arrangements and initiatives in place to try and prevent such situations arising."

\section{Difficult solutions}

Taking action against modern slavery is not straightforward, with the potential for action at government level to backfire. The US's CBP action last year, for instance, led to WRP Asia letting go of 1300 Bangladeshi and 57 Nepali workers in January 2020 when the company suspended production (now reversed)-with workers fearing deportation.

The ethical trade consultancy Impactt is one of several agencies demanding ethical recruitment and "remediating bonded labour" as the key to ending forced labour and debt bondage - with a successful case study at a Malaysian garment factory. That's not happening in medical trade, according to migrant worker specialist, Andy Hall.

"I've heard of only one agency in Nepal, out of more than 1200, that did direct worker recruitment, with potential employees telling me that a non-paid recruitment would be a scam," he told The BMJ. Rather than introducing sanctions, "a better response is for organisations to reward or benefit suppliers demonstrating good working conditions," he said.

Bhutta says that as well as changes in financial incentives to reward suppliers demonstrating good working conditions, "the culture of indifference and disrespect for migrant and other precarious workers needs to be tackled. That is something doctors themselves must support," he said.

"Healthcare professionals should care enough to do something about a situation that is unethical and illegal and affects the mental and physical health of hundreds of thousands-whether through propagating poverty, risking bodily injury, or through stress and depression from long working hours and a lack of respect at work," Bhutta said.

Former UK MEP Jude Kirton-Darling has called the situation "extremely worrying."

"Human rights are not a fair weather luxury and dispensable in our race for covid-19 medical supplies," she tweeted on 5 April. Hall said, "It's not a question of either increased glove production or protection of frontline health workers at high risk of forced labour. Both are crucial."

For Bhutta, lessons should be learnt from the difficulties of getting supplies of PPE during the covid-19 emergency. "We've learnt how reliant we are on manufacturers overseas and how precarious our supply chains can be."

"When negotiations with suppliers and manufacturers are dominated by low market prices and the dog eat dog world of a pure capitalist ideology, this is often linked to poor labour standards and volatile supply chains. By offering a fair price 
and asking suppliers to show respect for workers, backed by financial or contractual rewards, we can develop long term mutually beneficial relationships," Bhutta said.

\section{What can doctors do?}

Healthcare workers can be powerful advocates for ethical procurement within their organisation and in their dealings with suppliers.

The Ethical Procurement for Health workbook recommends that doctors: Raise awareness of labour abuses and campaign for their NHS organisation to purchase medical supplies ethically

Write to the chief executive of their NHS organisation, asking them to improve conditions for workers by implementing the Ethical Procurement for Health workbook

Show support and stay informed by the Fair Medical Trade group by visiting its website.

\section{Where our face masks come from}

With the sudden massive increase in demand for face masks, countries including the US have suddenly recognised the lack of homegrown manufacturing - with $95 \%$ of masks made much more cheaply in China or in Mexico in large industrial units close to the US border.

There have been reports of abuse from Hong Kong ${ }^{12}$ where prison authorities have been accused of modern slavery after forcing female inmates to work night shifts to produce millions of face masks to meet shortages.

Another US press report ${ }^{13}$ describes how "doctors on the front lines of the battle against coronavirus" seeking masks from factories in Mexico, navigated drug cartels and border agents demanding payoffs. "We joked that we felt like drug runners, except we weren't making a dime," John Henderson, chief executive of the Texas Organization of Rural and Community Hospitals, told LA Times.

Mahmood Bhutta witnessed poor working conditions in the manufacture of masks when he visited Mexico in 2010. "One factory owner I met said that because of the international price competition he had to remove his workers from the company payroll and convert them to homeworkers," he told The BMJ.

"I visited one of the factory's 250 homeworkers at his home. He would thread up to 1500 masks a day. But he is not a factory employee, so he doesn't get paid if he falls ill and can't work, and in that situation his children will help out."'
1 NHS Clinical Evaluation Team. Clinical review: examination gloves. July 2018. wwwmedia. supplychain.nhs.uk/media/Clinical-Review-for-Gloves-July-2018.pdf.

2 Ellis-Petersen H. NHS rubber gloves made in Malaysian factories linked with forced labour. Guardian. 9 December 2018. www.theguardian.com/global-development/2018/dec/09/ nhs-rubber-gloves-made-in-malaysian-factories-accused-of-forced-labour.

3 Bengtsen P. Clean gloves, dirty practices: debt bondage in Malaysia's rubber glove industry. The Diplomat. 22 November 2019. https://thediplomat.com/2019/11/clean-glovesdirty-practices-debt-bondage-in-malaysias-rubber-glove-industry.

4 Bhutta MF. Fair trade for surgical instruments. BMJ 2006;333:297-9.16877453

5 BMA, Ethical Trading Initiative, Department of Health, Medical Fair and Ethical Trade Group. Ethical procurement for health: workbook. www.bma.org.uk/media/1133/ethicaltrade-workbook-1.pdf.

6 Bhutta MF. Time for a global response to labour rights violations in the manufacture of health-care goods. Bull World Health Organ 2017;95:314-314A.28479628

7 BMA. Healthier procurement: report summary. March 2017. https://archive.bma.org.uk collective-voice/influence/international/global-justice/fair-medical-trade/surgical-toolsreport.

8 Pattisson P. NHS urged to avoid PPE gloves made in "slave-like" conditions. Guardian. 23 April 2020. www.theguardian.com/global-development/2020/apr/23/nhs-urged-to-avoidppe-gloves-made-in-slave-like-conditions-coronavirus.

9 Hall A. Don't forget the people behind the PPE: migrant workers meeting the surge in demand for medical gloves. 17 April 2020. www.telegraph.co.uk/global-health/scienceand-disease/dont-forget-people-behind-ppe-migrant-workersmeeting-surge.

10 Lee L, Das KN. Virus fight as risk as world's medical glove capital struggles with lockdown. Reuters. 25 March 2020. https://uk.reuters.com/article/uk-health-coronavirus-malaysiapackaging/virus-fight-at-risk-as-worlds-medical-glove-capital-struggles-with-lockdownidUKKBN21C12E.

11 HM Government. UK government modern slavery statement. 18 March 2020. https:// assets.publishing.service.gov.uk/government/uploads/system/uploads/attachment_data/ file/875800/UK_Government_Modern_Slavery_Statement.pdf.

12 Yi BL. Hong Kong denies "slavery" as prisoners work nights to make face masks. 10 March 2020. www.reuters.com/article/us-health-coronavirus-hongkong/hong-kong-deniesslavery-as-prisoners-work-nights-to-make-face-masks-idUSKBN20X205.

13 Levey NM. In Texas, a midnight run across the Mexican border gets masks for doctors. LA Times. 27 March 2020. www.latimes.com/politics/story/2020-03-27/masks-from-mexicodoctors-protective-equipment-shortages.

Published by the BMJ Publishing Group Limited. For permission to use (where not already granted under a licence) please go to http://group.bmj.com/group/rights-licensing/ permissions 